\title{
BIOCHEMICAL AND MOLECULAR MARKERS \\ ASSOCIATED WITH SALINITY TOLERANCE IN BREAD WHEAT GENOTYPES (TRITICUM AESTIVUM L.) UNDER SALINE CONDITIONS
}

\author{
Mahmoud M. El-Saber
}

Biochemistry Unit, Department of Genetic Resources, Desert Research Center, 11753 El-Matareya, Cairo, Egypt

E-mail: dr.mahmoud_saber@yahoo.com

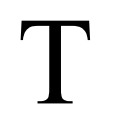

his investigation was applied to find out the seven bread wheat lines that are more tolerant to saline stress $(6195 \mathrm{ppm}$ soil and 8934 ppm irrigated water) at Ras Sudr, South Sinai, Egypt. Data indicated that bread wheat lines greatly varied in their ability to grow and subsequently assimilate and translocate biochemical components. Line1 (L1) surpassed the other lines, it was recorded the maximum values of growth, yield, and proline as well as the lowest malondialdehyde content followed by L3 and L7. ISSRPCR analysis was used for discriminating between lines. A total of 102 DNA bands are detected across the six ISSR primers, out of which only 72 bands (51 non-unique bands and 21 unique bands) are polymorphic with polymorphism percentages $(70.58 \%)$. In this regard, primer ISSR2 gave the highest polymorphism (92\%) followed by ISSR-13 (86\%) and ISSR-11 (78\%). Also, patterns of proteins (SDS-PAGE) and superoxide dismutase (SOD) have been successfully used in discriminating between salt-tolerant and saltsensitive lines. Concerning SDS-PAGE, bands number in 7 wheat lines ranged from 13 to 14 with molecular weights ranging between 6 to $130 \mathrm{kDa}$, and the more intensive bands are presented at 25,29 , and $34 \mathrm{kDa}$. Moreover, SOD patterns indicated the presence of 5 bands; the major is presented at bands (No. 4 and 5) in all wheat lines. Based on the results obtained, L1 was the best wheat line followed by L3 and L7 which more tolerant to saline stress, and this was associated with increasing growth, yield, and proline as well as decreasing MDA content. In conclusion, SDS-PAGE, SOD, and ISSR analyses are useful biochemical and molecular tools to discriminate different bread wheat lines under saline conditions.

Keywords: wheat, salinity, fingerprint, ISSR, SDS-protein, SOD 


\section{INTRODUCTION}

Salinity in the political and scientific agenda has become deeply relevant. Salinity affects over $6 \%$ of the total land area in the world and $20 \%$ of irrigated land (FAO, 2008). In some of these areas, the decline in the yield of different crops due to salinity is around 60 percent compared to normal soil (Bakry et al., 2014). Salinity induces osmotic stress and ionic toxicity due to the accumulation of sodium ion that enhances the formation of reactive oxygen species (ROS), such as, hydroxyl radical, singlet oxygen, hydrogen peroxide, and superoxide. Oxidative stress thus occurs and this leads to damage to mitochondria, chloroplasts, and the functional structure of the cells, which kills biomolecules including the lipids, proteins, nucleic acids, etc., causing lipid peroxidation, protein denaturation, and DNA mutation in plant cells (Mittler, 2002; Candan and Tarhan, 2003; Malagoli et al., 2008 and Sharma et al., 2012). Therefore, ROS is scavenged by various antioxidant defense mechanisms in plants that are both enzymatic and non-enzymatic (Ashraf, 2009). Several research studies have shown that plants are fitted with antioxidant enzymes toward ROS oxidative damage along with superoxide dismutase, catalase, peroxidase, and polyphenol oxidase (Vaidyanathan et al., 2003; Agarwal and Pandey, 2004; Mittova et al., 2004 and Bahari et al., 2013). Thus, overcoming the problem of salinity is not an easy task. Attempts to desalinate soil in reclamation projects could be highly expensive, and might even be impractical to desalinate in some areas. One other viable alternative would be to breed plants for salt-tolerant cultivars such as wheat and others.

Bread wheat (Triticum aestivum L.) is the universe's last main grain crop and occupies the earth's surface more than any other food crop (Kunika et al., 2019). The key problem for wheat breeders is increasing wheat production to reduce the difference between production and consumption (Maha et al., 2017). Consequently, much research is performed in the field of wheat breeding through genetic variability. However, further breakthroughs in wheat breeding are required for any increase in the population and climate change in the world. In any breeding program, achieving growth in heritage characteristics and estimating genetic parameters is of utmost importance (Elshafei et al., 2019). Therefore, most breeders focus on predicting or assessing the ability of genotypes to sustain yield under conditions of salinity stress compared to regulated conditions as an indicator of salinity stress tolerance (Negrão et al., 2017). Beneficial methods for detecting genetic variability between plant species, populations, and truths and identifying salinity markers are molecular markers (Randhawa et al., 2013). Molecular markers provide excellent sources of diversity to help breeders pick economic characteristics and thus improve crop productivity. Genetic relationship and diversity marker data are very important for any breeding program to select promising cultivars (Zhang et al., 2015). The DNA marker ISSR is effectively used to research plant genetic diversity (Etminan et al., 2016). ISSR is a

Egyptian J. Desert Res., 71, No. 1, 53-73 (2021) 
common marker for the evaluation of genetic diversity and is characterized by high polymorphism and recurrence (Zhang et al., 2016).

The real expressions of genes are proteins and enzymes. Protein and isozyme markers were therefore especially helpful in deducting systematic relationships between groups, where there were no corollary morphological and cytological results (Mahgoub et al., 2016). In many crop plants, the production of molecular markers for screening salt-tolerant genotypes has been attempted. A well-known adaptive mechanism for salt stress conditions in plants is the aggregation of osmolytes such as proline (Bakry et al., 2014). Numerous research studies have been performed on the function of proline and its role in salt stress tolerance as a compatible osmolyte and osmoprotectant. A few studies have associated proline with an antioxidant function, showing the activity of ROS scavenging and serving as a quencher (Matysik et al., 2002). Therefore, proline accumulation is considered an indicator for the selection of plants tolerant of different stress factors (VerdeStar et al., 2006). Salinity has a strong effect on lipid peroxidation of the plasma membrane, which indicates membrane damage and leakage under conditions of salt stress (Borzouei et al., 2012). Thus, the present study was therefore undertaken to fingerprint for seven wheat genotypes by evaluating the MDA, proline, ISSR, protein, and isozymes markers associated with the plants under salinity stress to identify the wheat genotypes with better performance in saline soils.

\section{MATERIALS AND METHODS}

\section{Plant Material and Experimental Design}

This study was conducted at the field station of the Experimental Farm of Desert Research Center, Ras-Sudr Research Station, South Sinai, Egypt $\left(29^{\circ} 35^{\prime} \mathrm{N}, 32^{\circ} 41^{\prime} \mathrm{E}\right)$ with salinity irrigation water, during the 2018 2019 growing season. The experimental materials consisted of 7 lines of bread wheat (L1, L2, L3, L4, L5, L6, and L7), presented in table (1), which have been obtained from the wheat breeding program, Plant Breeding Unit, Genetic Resources Department, Desert Research Center, Matareya, Egypt. This experiment was performed under a randomized complete block design with 3 replicates. Each line was planted in 6 rows of $2 \mathrm{~m}$ length, $20 \mathrm{~cm}$ apart, (plot size $\left.=6 \mathrm{~m}^{2}\right)$. The lines were grown under salinity soil $(6195 \mathrm{ppm})$ and irrigation water $(8934 \mathrm{ppm})$. All other agricultural practices were followed according to the recommendations of Ras Sudr region. Irrigated water from the well and soil were analyzed and presented in table (2). Fresh plants representing were collected after 45 days from sowing and ground into a fine powder using liquid nitrogen. The frozen samples of all lines in this study were kept frozen at $-80^{\circ} \mathrm{C}$ till use. Fresh samples were tested for malondialdehyde (MDA), proline, ISSR, the electrophoretic pattern of proteins, and superoxide dismutase (SOD) isozyme. The second one, 
represented by yield, was taken after harvesting (145 days from sowing) to determine plant height, number of grains/spike, 1000 grain weight and grain yield.

Table (1). Cod, name, and pedigree of bread wheat genotypes (Triticum aestivum L.).

(a) Parents cod, name and pedigree of bread wheat genotypes

\begin{tabular}{|c|c|c|c|c|c|}
\hline $\begin{array}{c}\text { Parents } \\
\text { code }\end{array}$ & Name & Pedigree & $\begin{array}{l}\text { Parents } \\
\text { code }\end{array}$ & Name & Pedigree \\
\hline $\mathrm{C} 1$ & Giza186 & $\begin{array}{c}\text { MIL/BUC//Seri CM 93046- } \\
\text { 8M-04-0M-2Y-0B-062 }\end{array}$ & $\mathrm{C} 5$ & Line63 & $\begin{array}{l}\text { CHAM-4/GRU90- } \\
202579\end{array}$ \\
\hline $\mathrm{C} 2$ & Acsad903 & $\begin{array}{c}\text { ACSAD52914/C18224/C168 } \\
\text { 3/3/Cno*2/7c//TopAcs-W- } \\
\text { 8024-20IZ-3IZ-4IZ-0IZ }\end{array}$ & $\begin{array}{l}\text { C6 } \\
\text { C7 }\end{array}$ & Cham6 & $\begin{array}{c}\text { CM39992-2M-7Y- } \\
\text { 0M-OAP } \\
\text { Azeghar- } \\
\text { 2/3/Mrf2//Bcr/Grol }\end{array}$ \\
\hline $\mathrm{C} 3$ & Acsad949 & $\begin{array}{l}\text { SNB, S, ASAD30SATS-W- } \\
\text { 8083-3IZ-5IZ-3IZ-0IZ }\end{array}$ & $\begin{array}{l}\mathrm{C} 8 \\
\mathrm{C} 9\end{array}$ & $\begin{array}{l}\text { V11 } \\
\text { V12 }\end{array}$ & $\begin{array}{l}\text { Bcr/Gro1//Mgnl1 } \\
\text { Geromtel-1/Icasyr-1 }\end{array}$ \\
\hline $\mathrm{C} 4$ & Line1 & TEVEE-I/SHUHA-C6 & $\mathrm{C} 10$ & Gemaiza7 & $\begin{array}{l}\text { CMH74 A. } \\
\text { 630/5x//Seri } \\
\text { 82/3/Agent }\end{array}$ \\
\hline
\end{tabular}

(b) Lines cod and pedigree

\begin{tabular}{clcl}
\hline Lines & Code & Lines & Code \\
\hline L1 & C5 $\times$ C2 & L5 & C $9 \times \mathrm{C} 10$ \\
L2 & C $5 \times$ C2 & L6 & C10 $\times$ C7 \\
L3 & C4 $\times$ C6 6 & L7 & C $8 \times$ C10 \\
L4 & C4 $\times$ C6 & & \\
\hline
\end{tabular}

Table (2). Water and soil chemical analysis.

\begin{tabular}{|c|c|c|c|c|c|c|c|c|c|}
\hline \multirow{2}{*}{$\mathrm{pH}$} & \multirow{2}{*}{$\begin{array}{c}\text { EC } \\
\text { ppm }\end{array}$} & \multicolumn{4}{|c|}{ Cations ( meq/l) } & \multicolumn{4}{|c|}{ Anions ( meq/l) } \\
\hline & & $\mathrm{Ca}^{++}$ & $\mathrm{Mg}^{++}$ & $\mathrm{Na}^{+}$ & $\mathrm{K}^{+}$ & $\mathrm{CO}_{3}^{-}$ & $\mathrm{HCO}_{3}{ }^{-}$ & $\mathrm{Cl}^{-}$ & $\mathrm{SO}_{4}^{--}$ \\
\hline \multicolumn{10}{|c|}{ Water analysis } \\
\hline 7.66 & 8934 & 19.3 & 13.8 & 105.1 & 0.90 & - & 7.50 & 93.1 & 38.7 \\
\hline \multicolumn{10}{|c|}{ Soil analysis } \\
\hline 7.76 & 6195 & 4.6 & 3.2 & 88.3 & 0.67 & - & 4.95 & 65.7 & 26.1 \\
\hline
\end{tabular}

2. Biochemical Markers

2.1. Malondialdehyde (MDA) content (lipid peroxidation)

In leaves, lipid peroxidation using malondialdehyde (MDA) content as a harm marker was calculated using the malondialdehyde (MDA) process according to Hernández et al. (2001).

Egyptian J. Desert Res., 71, No. 1, 53-73 (2021) 


\subsection{Free proline content}

Concerning the evaluation of free proline in wheat exposed to salinity, the techniques of Bates et al (1973) and Zúñiga et al. (1989), have been used. 2.3. Electrophoretic pattern of soluble proteins

Soluble proteins in leaves were determined according to SDS-PAGE gel electrophoresis was performed in acrylamide slab gels following the system of Laemmli (1970) and as modified by Studier (1973) to identify and separate the patterns of soluble proteins in wheat leaves.

2.4. Superoxide dismutase (SOD) isozyme

SOD was extracted from plant samples and separated by native polyacrylamide gel electrophoresis (PAGE) according to Weydert and Cullen (2010).

\section{Molecular Marker (ISSR-PCR Technique)}

Genomic DNAs were extracted from individual samples of frozen tissue following the procedure described by DNeasy Plant Mini Kit (Qiagen Inc., Cat. No. 69104, USA), which was performed as directed by the manufacturer. The concentrations and consistency of the genomic DNA samples were calculated on spectrophotometer ND-2000 (Nanodrop, USA). Finally, all genomic DNA samples were diluted with a TE buffer $(10 \mathrm{mM}$ TrisHC1, $\mathrm{pH} 8.0 ; 1 \mathrm{mM}$ EDTA) to a final concentration of $40 \mathrm{ng} / \mu \mathrm{l}$ and processed at $-20{ }^{\circ} \mathrm{C}$ for further use. In the detection of polymorphism, a package of 6 ISSR primers was used (Table 3). The amplification reaction was conducted at a volume of $25 \mu \mathrm{l}$ containing $1 \mathrm{X}$ PCR buffer, $1.5 \mathrm{mM} \mathrm{MgCl} 2$, $0.2 \mathrm{mM}$ dNTPs, $1 \mu \mathrm{M}$ primers, $1 \mathrm{U}$ Taq DNA polymerase, and $30 \mathrm{ng}$ DNA templates. After an initial denaturation period, PCR was programmed to accomplish 35 cycles at $94^{\circ} \mathrm{C}$ for 5 minutes. Each cycle was composed of a denaturation step for $1 \mathrm{~min}$ at $94^{\circ} \mathrm{C}$, an annealing step for $1 \mathrm{~min}$ at $50^{\circ} \mathrm{C}$, and an elongation step for $1.5 \mathrm{~min}$ at $72^{\circ} \mathrm{C}$. In the final cycle, the primer extension section was expanded to $7 \mathrm{~min}$ at $72^{\circ} \mathrm{C}$. The amplification products were resolved by electrophoresis in an ethidium bromide $(0.5 \mathrm{ug} / \mathrm{ml})$ containing $1.5 \%$ agarose gel in a $1 \mathrm{X}$ TAE buffer at 95 volts. As a DNA standard size marker, a $100 \mathrm{bp}$ DNA ladder was used. UV light was visualized and photographed on PCR products using a Gel Documentation Method (BIORAD 2000).

\section{Data Analysis}

To determine the genetic relationship of the samples under study, the banding patterns produced by ISSR-PCR marker analysis were compared. Clear and distinct amplification items were rated as ' 1 ' for the presence and ' 0 ' for the absence of bands. Bands with the same mobility were rated to be the same. The coefficient of genetic similarity (GS) between two genotypes was estimated by the Dice coefficient (Sneath and Sokal, 1973).

Dice formula: $\mathrm{GS}_{\mathrm{ij}}=2 \mathrm{a} /(2 \mathrm{a}+\mathrm{b}+\mathrm{c})$ 
Where GSij is the measure of genetic similarity between individuals $i$ and $j$, a is the number of bands shared by $i$ and $j, b$ is the number of bands present in $i$ and absent in $j$, and $c$ is the number of bands present in $j$ and absent in $i$. The matrix of similarity was used in evaluating the cluster. The study of the cluster was used to organize the data observed into coherent structures to establish taxonomies. In the first point, when each accession is a cluster of its own, the distances between these accessions are specified by the distance measurement chosen (Dice coefficient). However, the distance between two clusters is measured as the average distance between all accession pairs in the two related clusters until multiple accessions have been connected. This approach is referred to as the Unweighted Pair Group Process with Arithmetic Average (UPGMA) (Sneath and Sokal, 1973).

Table (3). List of the selected six ISSR primers for polymorphic DNA generation with the seven bread wheat lines (Triticum aestivum L.).

\begin{tabular}{cc}
\hline Name Primer & Sequence \\
\hline ISSR- 2 & 5'-AGAGAGAGAGAGAGAGYG-3' \\
ISSR- 8 & 5'-AGACAGACAGACAGACGC-3' \\
ISSR- 10 & 5'-GACAGACAGACAGACAAT-3' \\
ISSR- 11 & 5'-ACACACACACACACACYA-3' \\
ISSR- 13 & 5'-AGAGAGAGAGAGAGAGYT-3' \\
ISSR- 14 & 5'-CTCCTCCTCCTCCTCTT-3 \\
\hline
\end{tabular}

A: Adenine, C: Cytosine, G: Guanine and T: Thymine

\section{Statistical Analysis}

All the statistical analysis was performed using SPSS v 16.0 (SPSS Inc., 2007, Chicago, IL, USA) software program. The least significant difference (LSD) test was used to detect the significant differences among the items at a probability level (0.05) according to Gomez and Gomez (1984).

\section{RESULTS AND DISCUSSION}

\section{Growth and Yield Parameters \\ 1.1. Growth parameters}

Salinity stress caused a significant reduction in growth parameters e.g. plant height, fresh and dry weight of seven wheat lines (Fig. 1). In this regard, the maximum values of plant height, fresh and dry weight were recorded at lines $(1,7$, and 3$)$ respectively compared with other lines under salinity stress conditions. While L4 recorded the minimum values of growth parameters. These results were in complete harmony with obtained by Ashraf and Foolad (2007) and Sadeghi (2011) on barley and Zaki and Radwan (2011) on wheat. In the present study, under salinity stress, plant growth in seven genotypes was decreased, and it may be due to salinity stress that the normal physiological 
and biochemical activities of salinity-exposed plants were altered, leading to decreased growth. The hypothesis of the current research relating to the detrimental impact of salinity on plant biomass has also been supported by Munns et al. (2006) and Rahman et al. (2017). Similarly, Ndayiragije and Lutts (2006) also revealed that plants susceptible to salinity stress remain underdeveloped due to a reduction in cell division, elongation and also restricting the production of growth hormones (auxin), leading to a reduction in the total biomass of the affected plant.

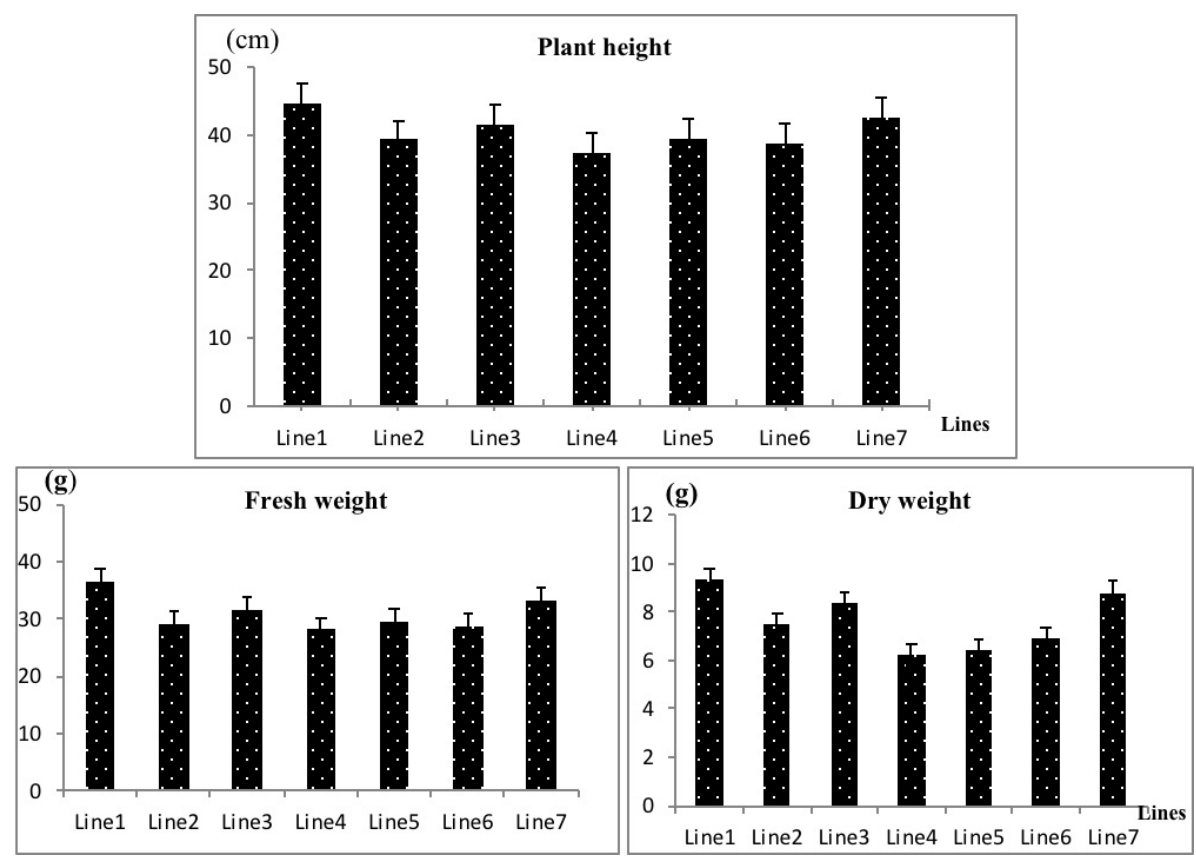

Fig. (1). Growth parameters histogram for seven wheat lines under saline conditions.

\subsection{Yield parameters}

Data presented in fig. (2) show that salinity affected negatively on yield and yield components (i.e., Plant height, Number of grains/spike, 1000Grain weight, and Grain yield by Ardab/ Feddan) of seven wheat lines. The results revealed that the highest values of plant height were found by line 1, 7 , and line 4 which recorded 94.17, 89.83, and 89.81, respectively. On the other hand, the lowest value of plant height was recorded by line 3 . Also, the maximum values of the number of grains/spikes were obtained by Line 6,4 , and 7 which recorded $(55.46,51.37$, and 50.73), respectively. The highest 1000 grain weight resulted from lines 5,7 , and 3 which recorded $62.89,62.42$, and $60.18 \mathrm{~g}$, respectively, while the lowest value has belonged to line 6 (47.74). Concerning the grain yield (Ardab/Fadden), line 1 gave the highest 
value of grain yield (14.93 Ardab/Fadden) followed by line 3 and line 7 which recorded 13.75 and 13.49 , respectively. The current results are similar to the findings obtained by several investigations, Turki et al. (2012) reported that the decline in grain yield could be caused by salinity, which caused photosynthetic ability to be decreased, leading to less synthesis of starch and grain accumulation. These results are in complete harmony with those obtained by (El-Saber et al., 2016 and Yassin et al., 2019a) on barley and wheat under salinity stress conditions. Many studies confirm the reduction of yield and its components under saline stress conditions, which may be due to: 1) loss of spike-bearing tillers (Maas et al., 1996). 2) Decrease in the number of the filled grains/plant and 1000 grain weight (Dutt, 1988). 3) Osmotic suppression of the absorption of water, excessive accumulation in plant cells of ions such as $\mathrm{Na}^{+}$or $\mathrm{Cl}^{-}$and/or sufficient absorption of vital nutrients (Munns and Termaat, 1986).

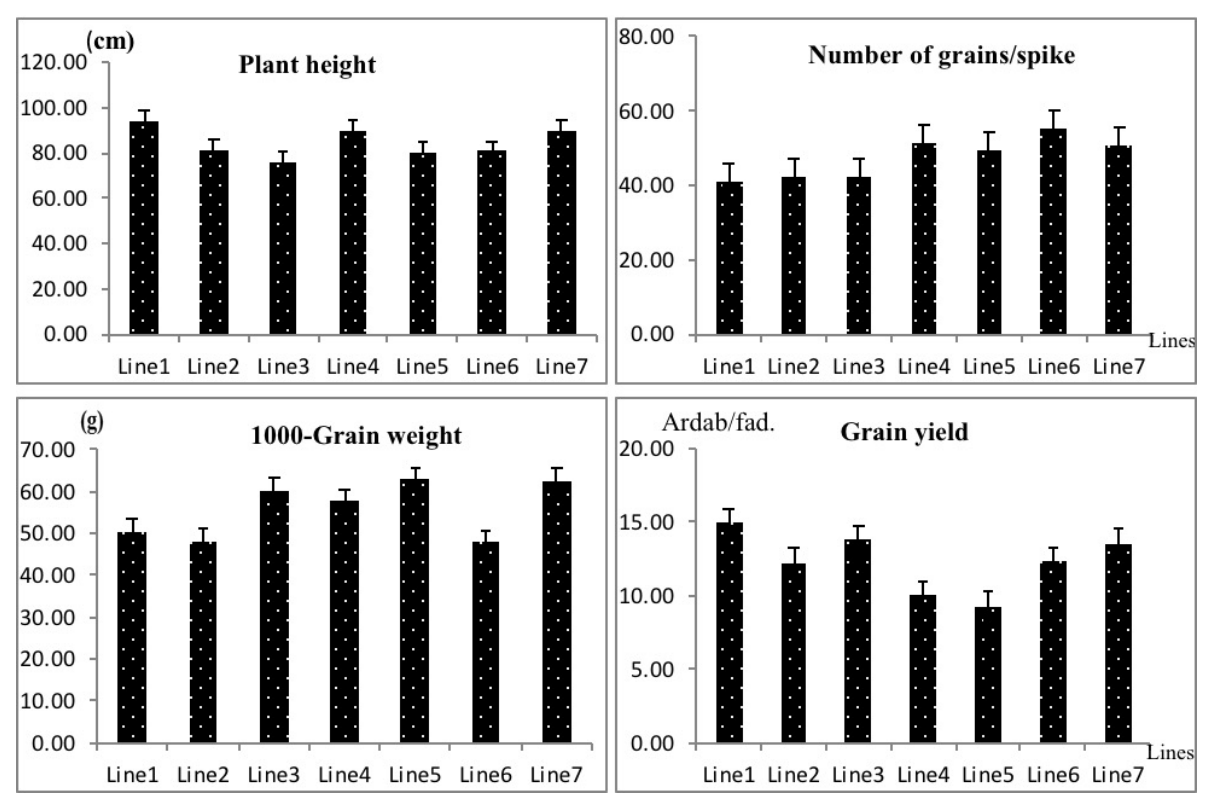

Fig. (2). Yield parameters histogram for seven wheat lines under saline conditions.

\section{Biochemical Markers}

\subsection{Lipid peroxidation}

The level of lipid peroxidation in wheat was quantified by the determination of malondialdehyde (MDA). Malondialdehyde content in leaves of seven wheat lines under saline stress is presented in fig. (3). Data demonstrated that salinity had a clear effect on the accumulation of malondialdehyde. In light of the results, the highest values of MDA were 
achieved in leaves of lines 4, 5 and 6 which recorded (331.3, 328.5 and 325.3 $\eta \mathrm{mol}$ / g FW), respectively. In contrast, the lowest values were found in lines 1, 3 and 7 which recorded 295.8, 309.4 and 311.2 $\eta \mathrm{mol} / \mathrm{g} \mathrm{FW}$, respectively. The accumulation of malondialdehyde under saline conditions is well documented by (Borzouei et al., 2012), who indicated that malondialdehyde content was higher in salt-sensitive wheat cultivar than salt-tolerant cultivar. In this connection, MDA release is one of the biochemical changes likely to be associated with adverse saline stress conditions and was used as a biomarker for assessing oxidative stress (El-Saber et al., 2016). A high concentration of MDA is associated with oxidative damage to the plant cell membranes in plant portions. Thus it was used to determine the level of oxidative damage under stressful conditions like salt stress (Yassin et al., 2019b).

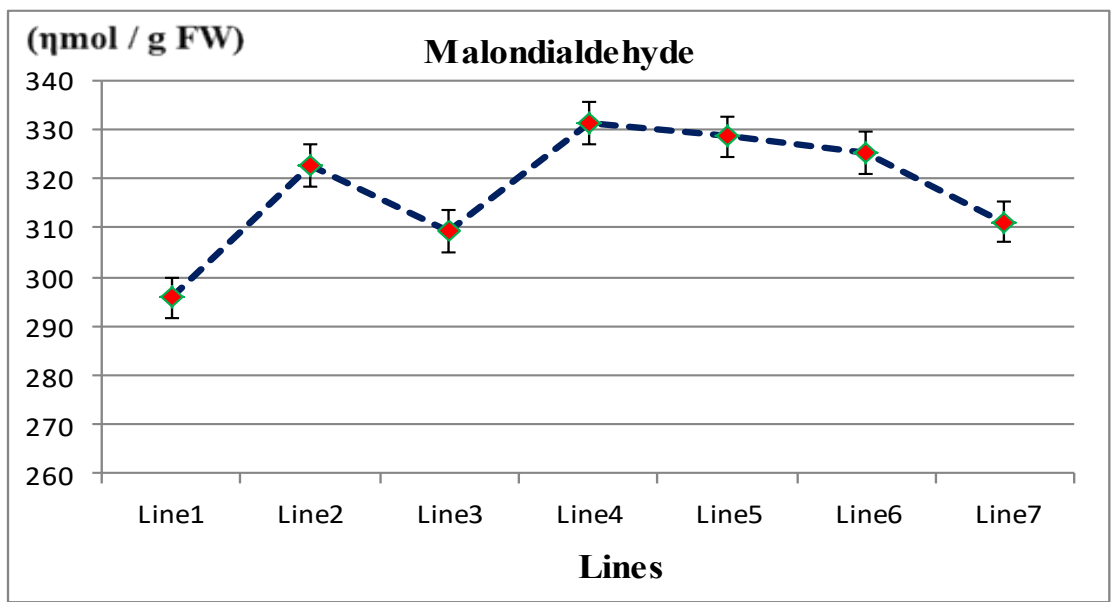

Fig. (3). Malondialdehyde content ( $\eta \mathrm{mol} / \mathrm{g}$ FW) in leaves of seven wheat lines under saline conditions.

\subsection{Proline content}

Accumulation of solutes especially proline is a common observation under salinity stress conditions. Data presented in fig. (4) showed that the accumulation of proline in seven wheat lines under salinity stress conditions. The results demonstrated that lines 1,7 , and 3 accumulated proline more than other genotypes which recorded 17.38, 16.72 and $15.69 \mu \mathrm{mol} / \mathrm{g} \mathrm{FW}$, respectively. The highest value was recorded by line 1 while line 4 gave the lowest proline content under the same conditions. Proline is an important osmolyte that synthesizing in plants exposed to salinity stress, thus it is an osmoses protector in the plant (Nazarbeygi et al., 2011). In this regard, the significant role of proline in plants under stress conditions was summarised by Hayat et al. (2012) as follows: 1) It defends the plants from different stresses and also allows plants to recover more quickly from stress. 2) 
Improved growth and other plant physiological features. 3) Scavenges produced by ROS in plants under different biotic and biotic stresses. 4) The preservation of cell turgidity under stress affects plant-water relationships and also increases the rate of photosynthesis. 5) Protects plants from damaging stresses such as salinity. Also, Kishor et al. (2005) observed that, under a variety of stress conditions, proline accumulation was due to increased synthesis and decreased degradation.

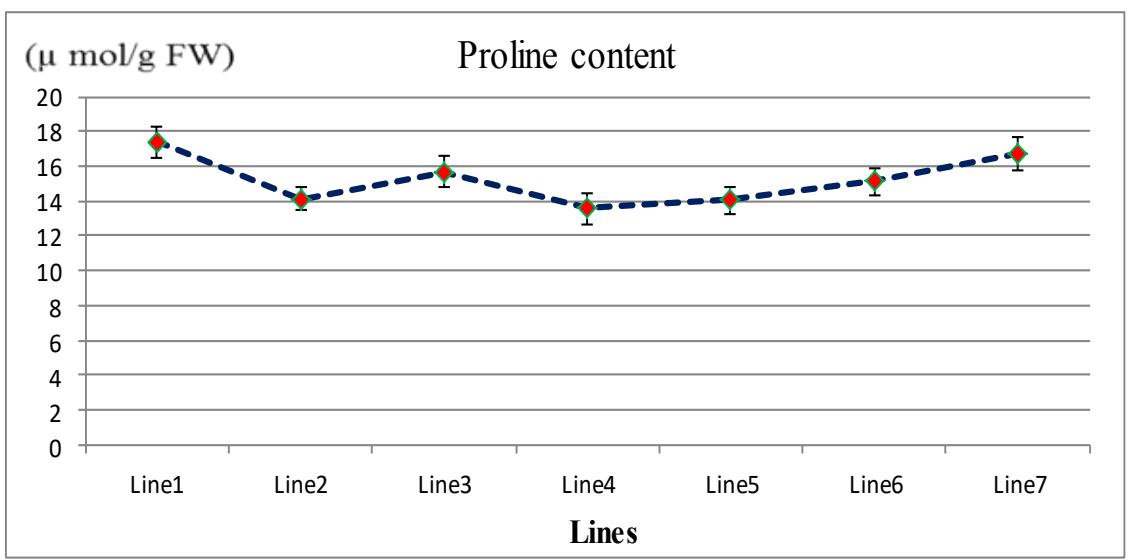

Fig. (4). Proline content ( $\mu \mathrm{mol} / \mathrm{g} \mathrm{FW})$ in leaves of seven wheat lines under saline conditions.

\subsection{Electrophoretic patterns of soluble proteins (SDS-PAGE)}

The data presented in fig. (5) and table (4) show that the number of bands in seven wheat lines ranged from 13 to 14 with molecular weights ranged between 6 to $130 \mathrm{kDa}$ under saline conditions. The more intensive bands are presented at molecular masses 25,29 , and $34 \mathrm{kDa}$ for all lines. Bands of molecular masses 6, 7, 10,12, 15, 25, 34, 50, 60, 82, and $130 \mathrm{kDa}$ appeared in all lines. In contrast, bands of molecular weights 8,18 , and 29 $\mathrm{kDa}$ were absent in lines $(1 \& 2), 3$, and $(4 \& 5)$ respectively. A unique band of molecular weight $17 \mathrm{kDa}$ appeared only in line 3 . The same effect was observed with the band of molecular mass $20 \mathrm{kDa}$ in line 4 .

Concerning band intensity, data showed an increase in band intensity in all lines under saline stress. The highest band intensity was recorded at molecular weight $34 \mathrm{kDa}$ compared with other molecular weights. However, the highest values were recorded in lines 3, 4 and 6 respectively. In this connection, protein accumulation under saline stress at low molecular weights may be linked to an increase in the synthesis of certain protein sets (new bands) as molecular chaperons under saline stress. Molecular chaperones are a wide mix of proteins involved in different cellular functions, including folding/unfolding, macromolecular assembly/disassembly, retaining proteins in their native state and preventing their aggregation under various stress 
conditions, helping to synthesize/degrade proteins, and targeting their cellular compartments (Boston et al., 1996). They were later interested in various physiological procedures and plant protection under stress conditions (Chen and Shimamoto, 2011).

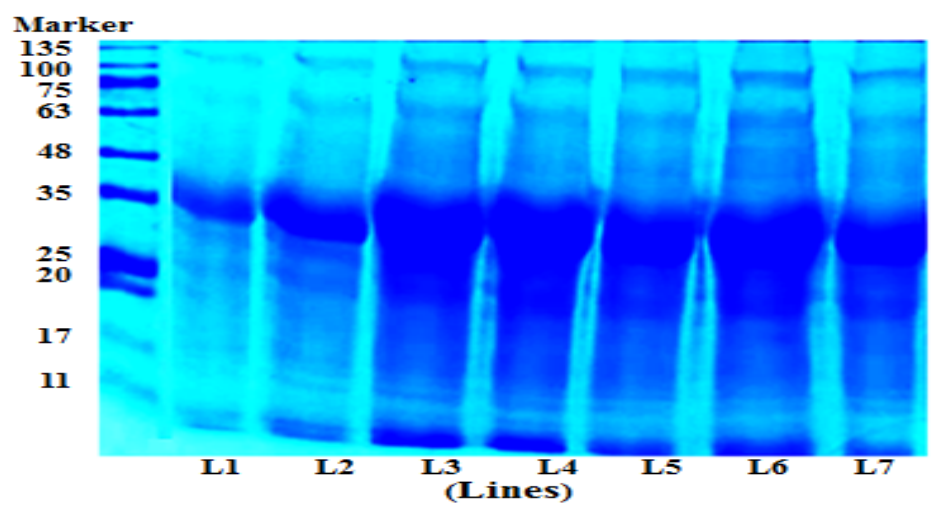

Fig. (5). SDS-PAGE profile of soluble protein extracted from seven wheat lines under saline conditions.

Table (4). SDS-PAGE patterns of soluble protein extracted from seven bread wheat lines under saline conditions.

\begin{tabular}{|c|c|c|c|c|c|c|c|c|}
\hline \multirow{2}{*}{$\begin{array}{c}\text { Molecular } \\
\text { weight } \\
\text { (kDa) }\end{array}$} & \multirow{2}{*}{$\begin{array}{c}\text { Band } \\
\text { number }\end{array}$} & \multicolumn{7}{|c|}{ Band intensity of bread wheat lines } \\
\hline & & L1 & $\mathbf{L 2}$ & $\mathbf{L 3}$ & L4 & L5 & L6 & L7 \\
\hline 130 & 1 & 2.3 & 2.6 & 2.9 & 3.4 & 3.0 & 3.1 & 3.2 \\
\hline 82 & 2 & 2.2 & 2.2 & 3.0 & 3.0 & 2.8 & 2.7 & 2.3 \\
\hline 60 & 3 & 1.8 & 2.5 & 2.7 & 2.4 & 1.9 & 2.9 & 2.1 \\
\hline 50 & 4 & 1.4 & 1.9 & 2.6 & 2.8 & 2.7 & 2.7 & 1.7 \\
\hline 34 & 5 & 7.8 & 10.8 & 15.9 & 15.6 & 13.7 & 15.3 & 12.9 \\
\hline 29 & 6 & 1.8 & 2.0 & 2.6 & 0.0 & 0.0 & 2.3 & 1.7 \\
\hline 25 & 7 & 2.3 & 2.1 & 2.1 & 2.7 & 2.7 & 2.5 & 2.3 \\
\hline 20 & 8 & 0.0 & 0.0 & 0.0 & 1.8 & 0 & 0.0 & 0.0 \\
\hline 18 & 9 & 2.0 & 1.8 & 0.0 & 2.8 & 2.3 & 3.0 & 0.0 \\
\hline 17 & 10 & 0.0 & 0.0 & 2.9 & 0.0 & 0.0 & 0.0 & 0.0 \\
\hline 15 & 11 & 1.6 & 2.2 & 2.4 & 3.4 & 1.8 & 2.5 & 3.7 \\
\hline 12 & 12 & 1.6 & 1.8 & 2.7 & 3.1 & 2.7 & 2.5 & 2.0 \\
\hline 10 & 13 & 1.2 & 1.7 & 2.2 & 2.0 & 2.0 & 1.7 & 2.4 \\
\hline 8 & 14 & 0.0 & 0.0 & 1.5 & 1.3 & 1.5 & 1.0 & 0.9 \\
\hline 7 & 15 & 1.2 & 2.0 & 2.1 & 2.4 & 2.3 & 2.5 & 1.6 \\
\hline 6 & 16 & 1.6 & 1.7 & 2.5 & 2.7 & 2.2 & 2.1 & 1.5 \\
\hline \multicolumn{2}{|c|}{ Total } & 13 & 13 & 14 & 14 & 13 & 14 & 13 \\
\hline
\end{tabular}

Where: $0=$ no bands, $1.00=$ refers to the lowest band intensity, $15.9=$ refers to the highest band intensity. 


\subsection{Superoxide dismutase isozyme (SOD)}

SOD isoforms have been well reported under salt stress conditions in table (5) in the seven wheat lines. SOD patterns indicated the presence of 5 bands for the seven wheat lines. The more intensive bands are presented at band numbers 4 and 5 in all lines under saline conditions. Band No.1 was absent in L4, also band No. 2 was absent in L3 and L4. However, band No.3 was presented in lines 5, 6, and 7 only as well as absent in other wheat lines. Concerning band intensity, data showed an increase under saline stress conditions. By comparing band intensity for the seven bread wheat lines, the highest band intensities were recorded in lines 5, 6, and 7. In addition, band No. 1 and 5 of line 7 gave the maximum values of band intensities under the same conditions. In this link, plant cells contain several antioxidants for reducing or repairing ROS damage and for controlling redox-sensitive cellular processes. SOD transform radical superoxide into hydrogen peroxide and molecular oxygen (Weydert and Cullen, 2010). Furthermore, SOD isoforms often respond differentially to various environmental stresses. Mauro et al. (2005) showed the significance of the SOD system's qualitative existence in the scavenging of superoxide radicals.

Table (5). Superoxide dismutase isozyme (SOD) profile of seven bread wheat lines under saline conditions.

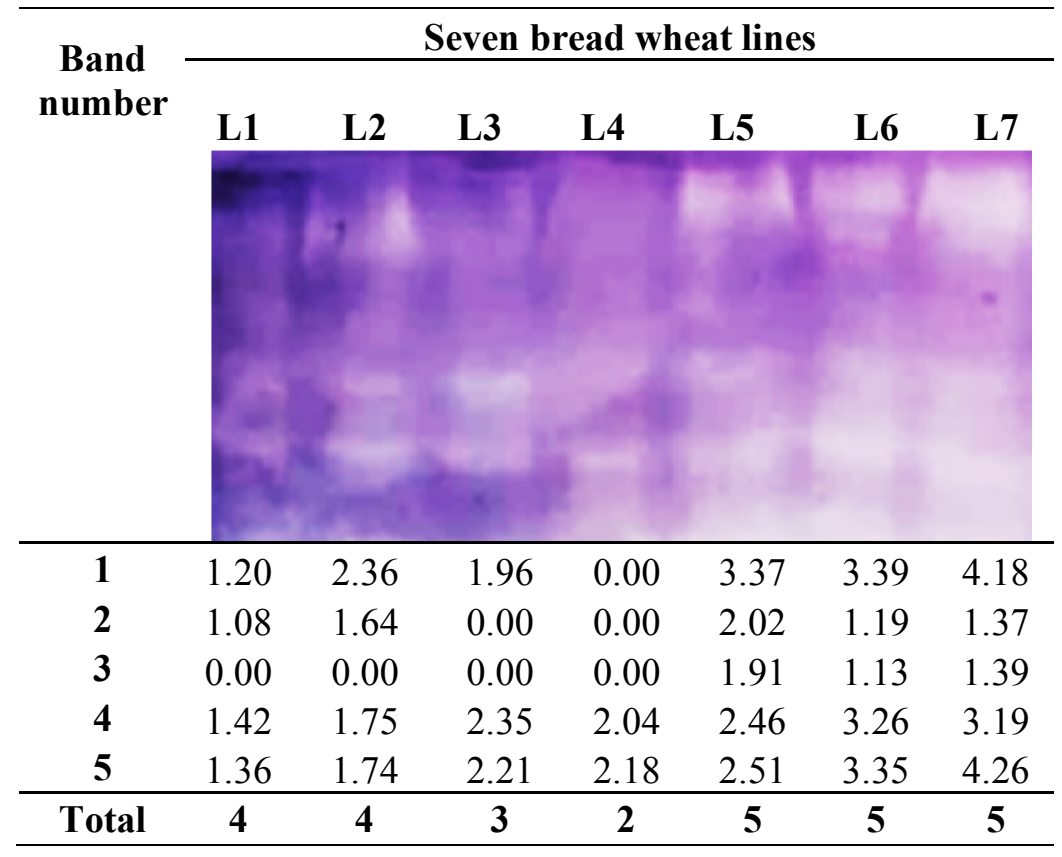

\section{Molecular marker (ISSR-PCR)}

The selected 6 ISSR primers used for the study of genetic diversity and the relationship of seven bread wheat lines (Triticum aestivum L.) 
developed amplification products and polymorphic fingerprint patterns. A total of 102 DNA fragments were detected for ISSR-PCR analysis (Fig. 6 and Table 6), with an average of 17 bands per primer, 72 bands were polymorphic, and 30 bands were monomorphic. To determine the degree of polymorphism in the group of 7 bread wheat lines studied, the number of polymorphic bands ranged from $15 \%$ to $92 \%$ with an average of $65.5 \%$. The most polymorphic of the amplified DNA bands ranged from 130 to 1500 base pairs (bp) in size Primer ISSR-2, where 22 polymorphic amplification products were detected. Primer ISSR-10 detected the smallest number of amplified polymorphic fragments (2). The band frequency mean was 0.4 (ISSR-2 and ISSR-13) to 0.9 (ISSR-10) with 0.57 on average.

The similarity matrix (the similarity coefficient of the Jaccard) showed that the highest similarity percentage was obtained with 0.80 between the 1 and 2 lines, whereas the lowest similarity percentage was obtained with 0.67 between the 3,4, and 3,7 lines and the average genetic similarity coefficient (GS) was 0.735 between them (Table 7).

A dendrogram was developed using the Arithmetic Mean Unweighted Pair Group Method (UPGMA) similarity matrix that specifically discriminated against the genotypes of wheat. The cluster analysis was carried out using the similarity coefficients of Jaccard to research the genetic relations between these lines of wheat (Fig. 7). The produced dendrogram divided the lines into four sets. Set I contained two lines (4 and 6). Set 2 clustered together with two lines (5 and 7). Set 3 included two lines (1 and 2). Set 4 was made of a single line 3 . These findings indicated the use of cluster analysis to distinguish the salt-tolerant lines apart from the sensitive lines. Analysis of DNA using ISSR-PCR has proven to be excellent markers for providing molecular data to test genetic variation and has been successfully used to classify genetic relationships for many other plants. In this regard, El-Sayed and Ibrahim (2008) reported genetic diversity among ten genotypes of double haploid (DH) and five varieties of bread wheat grown in high salinity soil by the ISSR. They noticed that 31 polymorphic fragments with 58.4 percent polymorphism from a total of 56 amplified fragments under salinity stress were seen in an ISSR analysis using four different salinity tolerance primers. The four wheat genotypes identified 22 different markers with $41 \%$ polymorphism for salinity tolerance, while in the current study we found $65.5 \%$ polymorphism among 7 genotypes. A similar result was also reported that ISSR markers are used to examine the genetic diversity and relationships between eight Egyptian wheat cultivars (Shandweel-1, Misr-2, Sakha-93, Sakha-94, Giza-168, Giza-171, Sids-1, and Gemmiza-9) by Abdel-Lateif and Hewedy (2018). They noted that ISSR primers formed 34 bands and 23 of these bands $(68 \%)$ were polymorphic. These studies have shown strong sources of diversity that will help breeders determine genetic diversity and pick economically relevant characteristics such as salinity tolerance. The same result is stated in previous studies and this shows the importance of ISSR 
markers in polymorphism detection and the establishment of specific genetic relations (Pakseresht et al., 2013 and Etminan et al., 2016).
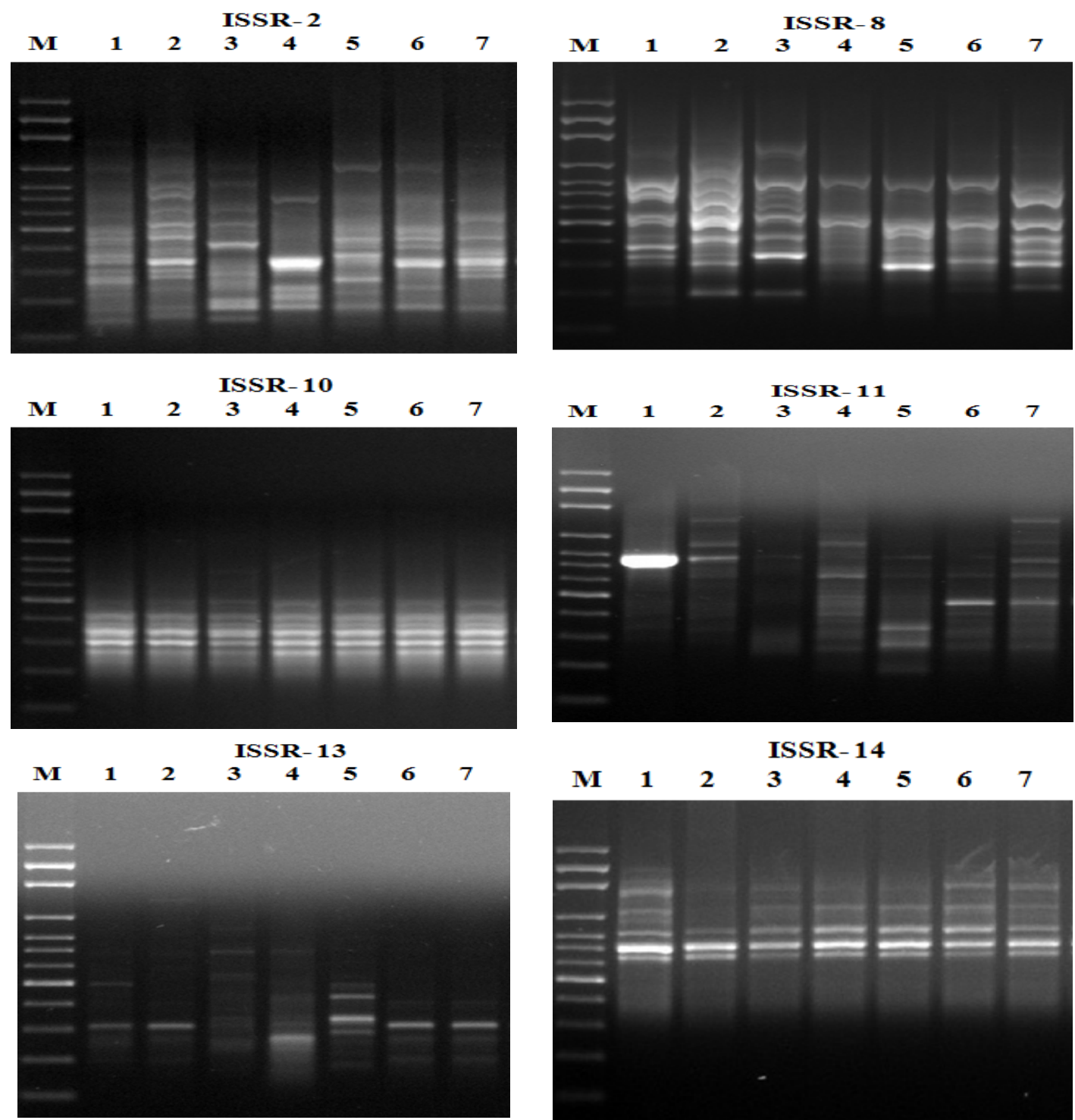

Fig. (6). ISSR amplification patterns obtained using six primers in 1.5\% agarose gel electrophoreses. (M) referred to molecular marker size of 100bp DNA ladder, (1 to 7) samples from bread wheat lines.

Egyptian J. Desert Res., 71, No. 1, 53-73 (2021) 
Table (6). The banding pattern and polymorphism generated by the six ISSR primers for the seven bread wheat lines.

\begin{tabular}{|c|c|c|c|c|c|c|c|c|}
\hline \multirow{2}{*}{$\begin{array}{l}\text { Primer } \\
\text { Name }\end{array}$} & \multirow{2}{*}{ bp } & \multirow{2}{*}{$\begin{array}{l}\text { Monomorphic } \\
\text { bands }\end{array}$} & \multicolumn{3}{|c|}{ Polymorphic bands } & \multirow{2}{*}{$\begin{array}{l}\text { Total } \\
\text { bands }\end{array}$} & \multirow{2}{*}{$\begin{array}{c}\text { Polymorphism } \\
\text { (\%) }\end{array}$} & \multirow{2}{*}{$\begin{array}{c}\text { Band } \\
\text { frequency }\end{array}$} \\
\hline & & & $\begin{array}{c}\text { Non } \\
\text { unique }\end{array}$ & Unique & Total & & & \\
\hline $\begin{array}{l}\text { ISSR- } \\
2\end{array}$ & $130-1500$ & 2 & 18 & 4 & 22 & 24 & 92 & 0.4 \\
\hline $\begin{array}{l}\text { ISSR- } \\
8\end{array}$ & $180-1250$ & 5 & 13 & 4 & 17 & 22 & 77 & 0.5 \\
\hline $\begin{array}{l}\text { ISSR- } \\
10\end{array}$ & $210-680$ & 11 & 1 & 1 & 2 & 13 & 15 & 0.9 \\
\hline $\begin{array}{l}\text { ISSR- } \\
11\end{array}$ & $160-1400$ & 4 & 11 & 3 & 14 & 18 & 78 & 0.6 \\
\hline $\begin{array}{l}\text { ISSR- } \\
13\end{array}$ & $150-1400$ & 2 & 6 & 6 & 12 & 14 & 86 & 0.4 \\
\hline $\begin{array}{l}\text { ISSR- } \\
14\end{array}$ & $720-2000$ & 6 & 2 & 3 & 5 & 11 & 45 & 0.6 \\
\hline \multicolumn{2}{|c|}{ Total } & 30 & 51 & 21 & 72 & 102 & 70 & 3.4 \\
\hline \multicolumn{2}{|c|}{ Mean per primer } & 5 & 8.5 & 3.5 & 12 & 17 & 65.5 & 0.57 \\
\hline
\end{tabular}

Table (7). Genetic similarity (Jacquard's) among the seven wheat lines by ISSR pattern generated by six ISSR primers.

\begin{tabular}{cccccccc}
\hline Lines & L1 & L2 & L3 & L4 & L5 & L6 & L7 \\
\hline 1 & 100 & & & & & & \\
2 & 80 & 100 & & & & & \\
3 & 70 & 70 & 100 & & & & \\
4 & 68 & 68 & 67 & 100 & & & \\
5 & 70 & 68 & 68 & 71 & 100 & 100 & \\
6 & 71 & 69 & 68 & 79 & 78 & 77 & 100 \\
7 & 74 & 76 & 67 & 75 & 72 & \\
\hline
\end{tabular}




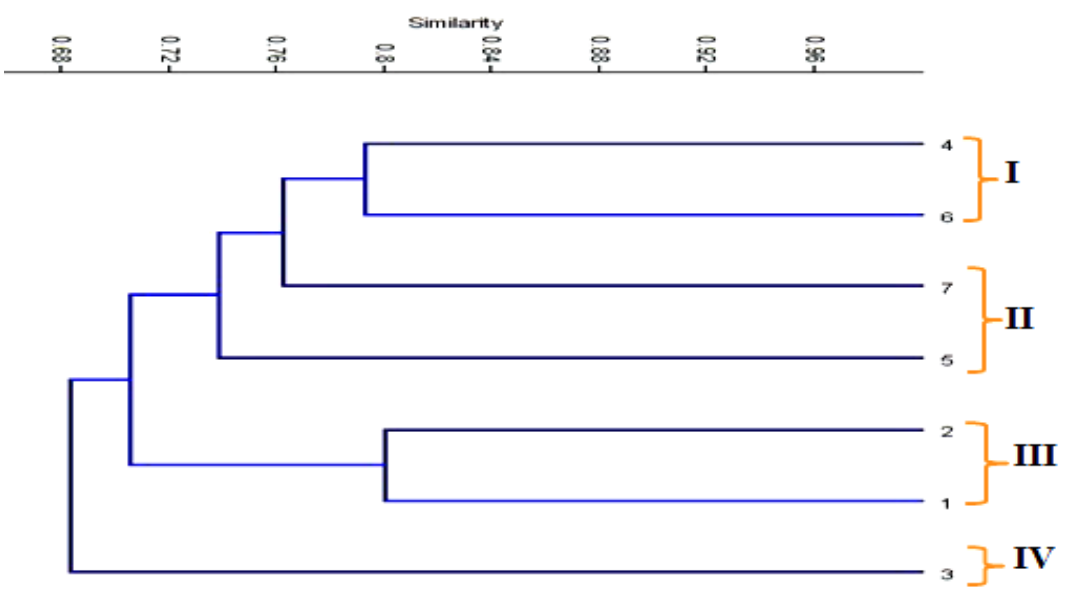

Fig. (7). The dendrogram cluster tree generated by using classify UPGMA cluster analysis based on Jaccard's similarity coefficients obtained from ISSR primers for the seven wheat lines.

\section{CONCLUSION}

In light of the findings, it can be concluded that lines 1,3 , and 7 were more tolerant to salinity stress than the other lines. This was evident in growth, yield parameters, increasing proline accumulation, decreasing MDA content, and molecular markers associated with salinity tolerance ISSR, SDS-PAGE, and SOD isozyme markers, which are well correlated with their adaptive strategy to salt stress for the seven bread wheat lines. Specific positive marker detection may be of great benefit to breeding programs to predict the most tolerant cultivars. ISSR techniques are efficient methods for detecting specific salinity tolerance markers, but experimental studies need to be done to establish the relationship between these ISSR markers, protein and isozyme markers, and the salt tolerance gene(s) responsible for these wheat lines.

\section{REFERENCES}

Abdel-Lateif, K. and O. Hewedy (2018). Genetic diversity among Egyptian wheat cultivars using SCoT and ISSR markers. SABRAO J. Breed. Genet., 50: 36-45.

Agarwal, S., and V. Pandey (2004). Antioxidant enzyme responses to $\mathrm{NaCl}$ stress in Cassia angustifolia. Biol. Plant., 48: 555-560.

Ashraf, M. (2009). Biotechnological approach of improving plant salt tolerance using antioxidants as markers. Biotechnol. Adv., 27: 84-93.

Egyptian J. Desert Res., 71, No. 1, 53-73 (2021) 
Ashraf, M. and M.R. Foolad (2007). Roles of glycine betaine and proline in improving plant abiotic stress resistance. Environ. Exp. Bot., 59: 206216.

Bahari, A., H. Pirdashti, and M. Yaghubi (2013). The effects of amino acid fertilizers spraying on photosynthetic pigments and antioxidant enzymes of wheat (Triticum aestivum L.) under salinity stress. Int. J. Agron. Plant Prod., 4: 787-793.

Bakry, B.A., M. H. Taha, Z.A. Abdelgawad and M.M.S. Abdallah (2014). The role of humic acid and proline on growth, chemical constituents, and yield quantity and quality of three flax cultivars grown under saline soil conditions. Agric. Sci., 5: 1566-1575.

Bates, L.S., R.P. Waldren and I. Teare (1973). Rapid determination of free proline for water-stress studies. Plant Soil, 39: 205-207.

Borzouei, A., M. Kafi, E. Akbari-Ghogdi and M. Mousavi-Shalmani (2012). Long term salinity stress in relation to lipid peroxidation, superoxide dismutase activity, and proline content of salt-sensitive and salttolerant wheat cultivars. Chil. J. Agric. Res., 72: 476- 482.

Boston, R.S., P.V. Viitanen and E. Vierling (1996). Molecular chaperones and protein folding in plants. Plant Mol. Biol., 32: 191-222.

Candan, N. and L. Tarhan (2003). The correlation between antioxidant enzyme activities and lipid peroxidation levels in Mentha pulegium organs grown in $\mathrm{Ca}_{2}{ }^{+}, \mathrm{Mg}_{2}{ }^{+}, \mathrm{Cu}_{2}{ }^{+}, \mathrm{Zn}_{2}{ }^{+}$, and $\mathrm{Mn}_{2}{ }^{+}$stress conditions. Plant Sci., 165: 769-776.

Chen, L. and K. Shimamoto (2011). Emerging roles of molecular chaperones in plant innate immunity. J. General Plant Pathol., 77: 1-9.

Dutt, S. (1988). Soil salinity effects on the process of grain filling in barley (Hordeum vulgare L.) varieties. Indian J. Plant Physiol., 31: 222-227.

El-Saber, M.M., R. El-Massry, H. Kamel and M. Hendawey M. (2016). Emino amino acids accumulation and its implication in barley tolerance to salt stress under ras sudr conditions, South saini, Egypt. Zag. J. Agric. Res., 43: 533-554.

El-Sayed, O.E. and H.F. Ibrahim (2008). Development of RAPD and ISSR markers associated with salt tolerance in bread wheat using in vitro culture. Middle East Russ. J. Plant Sci. Biotech., 2: 52-59.

Elshafei, A., S. Afiah, M. Amer and A. Magda (2019). Validation of molecular markers linked with salinity tolerance in wheat (Triticum aestivum L.) grown on saline soil. Biosci. Res., 16: 963-978.

Etminan, A., A. Pour-Aboughadareh, R. Mohammadi, A. Ahmadi-Rad, A. Noori, Z. Mahdavian and Z. Moradi (2016). Applicability of start codon targeted (SCoT) and inter-simple sequence repeat (ISSR) markers for genetic diversity analysis in durum wheat genotypes. Biotech. Biotechnol. Equip., 30: 1075-1081.

FAO (2008). The State of Food Insecurity in the World. High Food Prices and Food Security. Threats and Opportunities. Food and Agriculture 
Organization of the United Nations, Rome, Italy. Available online: http://www .fao.org/docrep/ 011/i0291e/i029 1e00.htm.

Gomez, K.A. and A.A. Gomez (1984). In: "Statistical Procedures for Agricultural Research". John Wiley and Sons. (2 $2^{\text {nd }}$ Ed.). New York: Wiley, $680 \mathrm{p}$.

Hayat, S., Q. Hayat, M.N. Alyemeni, A.S. Wani, J. Pichtel and A. Ahmad (2012). Role of proline under changing environments: a review. Plant Signal Behav., 7: 1456-1466.

Hernández, J.A., M.A. Ferrer, A. Jiménez, A.R. Barceló and F. Sevilla (2001). Antioxidant systems and $\mathrm{O}_{2} .-1 \mathrm{H}_{2} \mathrm{O}_{2}$ production in the apoplast of pea leaves. Its relation with salt-induced necrotic lesions in minor veins. Plant Physiol., 127: 817-831.

Kishor, P.K., S. Sangam, R. Amrutha, P.S. Laxmi, K. Naidu, K.S. Rao, S. Rao, K. Reddy, P. Theriappan and N. Sreenivasulu (2005). Regulation of proline biosynthesis, degradation, uptake and transport in higher plants: its implications in plant growth and abiotic stress tolerance. Curr. Sci., 424-438.

Kunika, B.K., P.K. Singh, V. Rani and G.C. Pandey (2019). Salinity tolerance in wheat: An overview. Int. J. Chem. Stud., 6: 815-820.

Laemmli, U.K. (1970). Cleavage of structural proteins during the assembly of the head of bacteriophage T4. Nature, 227: 680-685.

Maas, E.V., S.M. Lesch, L.E. Francois and C.M. Grieve (1996). Contribution of individual culms to yield of salt-stressed wheat. Crop Sci., 36: 142149.

Maha, A., I. Sanaa, Y. Mabrook, Y. Amira and M. Gouda (2017). Evaluation of some Egyptian bread wheat (Triticum aestivum) cultivars under salinity stress. Alex. Sci. Exch. J., 38 (2): 259-270.

Mahgoub, H., A.R. Sofy, E.A. Abdel-Azeem and M.S. Abo-Zahra (2016). Molecular markers associated with salt-tolerance of different soybean (Glycine $\max$ L.) cultivars under salt stress. Int. J. Adv. Res. Biol. Sci., 3: 241-267.

Malagoli, P., D.T. Britto, L.M. Schulze and H.J. Kronzucker (2008). Futile $\mathrm{Na}+$ cycling at the root plasma membrane in rice (Oryza sativa L.): kinetics, energetics, and relationship to salinity tolerance. J. Exp. Bot., 59: 4109-4117.

Matysik, J., A.B. Bhalu, and P. Mohanty (2002). Molecular mechanisms of quenching of reactive oxygen species by proline under stress in plants. Curr. Sci., 525-532.

Mauro, S., F. Van Eycken, N. Challou, P. Lucas and M. L'Oiseau (2005). Characterization of new maize chloroplastic copper/zinc superoxide dismutase isoforms by high resolution native two-dimensional polyacrylamide gel electrophoresis. Identification of chilling responsive chloroplastic superoxide dismutase isoforms. Physiol. Plant., 124: 323-335.

Egyptian J. Desert Res., 71, No. 1, 53-73 (2021) 
Mittler, R. (2002). Oxidative stress, antioxidants, and stress tolerance. Trends Plant Sci., 7: 405-410.

Mittova, V., M. Guy, M. Tal and M. Volokita (2004). Salinity up-regulates the antioxidative system in root mitochondria and peroxisomes of the wild salt-tolerant tomato species Lycopersicon pennellii. J. Exp. Bot., 55: 1105-1113.

Munns, R., R.A. James and A. Läuchli (2006). Approaches to increasing the salt tolerance of wheat and other cereals. J. Exp. Bot., 57: 1025-1043.

Munns, R. and A. Termaat (1986). Whole-plant responses to salinity. Funct. Plant Biol., 13: 143-160.

Nazarbeygi, E., H.L. Yazdi, R. Naseri and R. Soleimani (2011). The effects of different levels of salinity on proline and A-, B-chlorophylls in canola. Am. Eurasian J. Agric. Environ. Sci., 10: 70-74.

Ndayiragije, A. and S. Lutts (2006). Do exogenous polyamines have an impact on the response of a salt-sensitive rice cultivar to $\mathrm{NaCl}$ ? Plant Physiol., 163: 506-516.

Negrão, S., S. Schmöckel and M. Tester (2017). Evaluating physiological responses of plants to salinity stress. Ann. Bot., 119: 1-11.

Pakseresht, F., R. Talebi and E. Karami (2013). Comparative assessment of ISSR, DAMD, and SCoT markers for evaluation of genetic diversity and conservation of landrace chickpea (Cicer arietinum L.) genotypes collected from the north-west of Iran. Physiol. Mol. Biol. Plants, 19: 563-574.

Rahman, M.M., F. Zahan, S.I. Sikdar, A. El Sabagh, D. Ratnasekera, C. Barutcular and M.S. Islam (2017). Evaluation of salt tolerance mungbean genotypes and mitigation of salt stress through potassium nitrate fertilization. Fresen. Environ. Bull., 26: 7218-7226.

Randhawa, H.S., M. Asif, C. Pozniak, J.M. Clarke, R.J. Graf, S.L. Fox, D.G. Humphreys, R.E. Knox, R.M. DePauw and A.K. Singh (2013). Application of molecular markers to wheat breeding in Canada. Plant Breed., 132: 458-471.

Sadeghi, H. (2011). Use of new barley cultivar to improve salt tolerance and yield in cultivated barley (Hordeum vulgare L.). Afr. J. Agric. Res., 6: 4778-4784.

Sharma, P., A.B. Jha, R.S. Dubey and M. Pessarakli (2012). Reactive oxygen species, oxidative damage, and antioxidative defense mechanism in plants under stressful conditions. J. Bot., 2012:1-26.

Sneath, P.H. and R.R. Sokal (1973). In: "Numerical Taxonomy". The Principles and Practice of Numerical Classification. San Francisco, 573 p.

Studier, F.W. (1973). Analysis of bacteriophage T7 early RNAs and proteins on slab gels. J. Mol. Biol., 79: 237-248. 
Turki, N., M. Harrabi and K. Okuno (2012). Effect of salinity on grain yield and quality of wheat and genetic relationships among durum and common wheat. J. Arid Land Stud., 22: 311-14.

Vaidyanathan, H., P. Sivakumar, R. Chakrabarty and G. Thomas (2003). Scavenging of reactive oxygen species in $\mathrm{NaCl}$-stressed rice (Oryza sativa L.) - differential response in salt-tolerant and sensitive varieties. Plant Sci., 165: 1411-1418.

Verde-Star, J., R. Maiti, P.R. Foroughbakhch, H. Gámez-González, S. Martinez-Lozano, M. Núñez-González, G.G. Díaz, J. HernándezPiñero, and M. Morales-Vallarta (2006). Variability in accumulation of free proline on in vitro calli of four bean (Phaseolus vulgaris L.) varieties exposed to salinity and induced moisture stress. Phyton., 75: 103-108.

Weydert, C.J. and J.J. Cullen (2010). Measurement of superoxide dismutase, catalase, and glutathione peroxidase in cultured cells and tissue. Nat. Protoc., 5: 51-66.

Yassin, M., S.A. Fara, A. Hossain, H. Saneoka and A. El Sabagh (2019a). Assessment of salinity tolerance bread wheat genotypes: using stress tolerance indices. Fresenius Environ. Bull., 28: 4199-4217.

Yassin, M., A. El Sabagh, A. Mekawy, M. Islam, A. Hossain, C. Barutcular, H. Alharby, A. Bamagoos, L. Liu and A. Ueda (2019b). Comparative performance of two bread wheat (Triticum aestivum L.) genotypes under salinity stress. Appl. Ecol. Environ. Res., 17: 5029-5041.

Zaki, R. and T. Radwan (2011). Improving wheat grain yield and its quality under salinity conditions at a newly reclaimed soil by using different organic sources as soil or foliar applications. J. Appl. Sci. Res., 4255.

Zhang, J., W. Xie, Y. Wang and X. Zhao (2015). Potential of start codon targeted (SCoT) markers to estimate genetic diversity and relationships among Chinese Elymus sibiricus accessions. Molecules, 20: 5987-6001.

Zhang, Y., H. Yan, X. Jiang, X. Wang, L. Huang, B. Xu, X. Zhang and L. Zhang (2016). Genetic variation, population structure, and linkage disequilibrium in Switchgrass with ISSR, SCoT, and EST-SSR markers. Hereditas, 153: 1-12.

Zúñiga, G.E., V.H. Argandoña and L.J. Corcuera (1989). Distribution of glycine-betaine and proline in water-stressed and unstressed barley leaves. Phytochemistry, 28: 419-420.

Egyptian J. Desert Res., 71, No. 1, 53-73 (2021) 


\section{العلامات الكيميائية الحيوية والجزيئية المرتبطة بتحمل الملوحة في التراكيب المبي الوراثية لقمح الخبز تحث الظزئة الظروف الملحية بحلية}

محمود محمد الكيمياء الحيوية، قسم الأصول الور اثية، مركز بحوث الصحر اء، المطرية، القاهرة،

تم إجراء هذا البحث لمعرفة سبع سلالات من قمح الخبز الأكثر تحملً للإجهاد الملحي

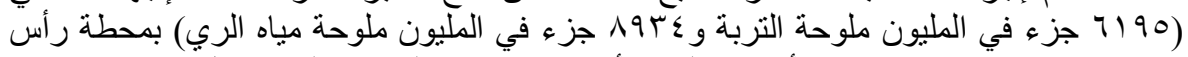

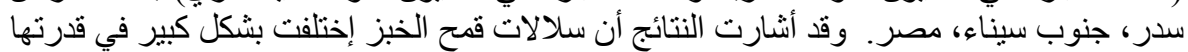

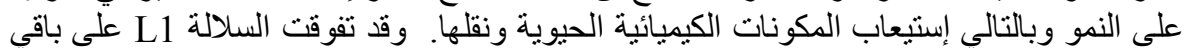

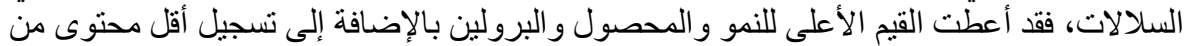

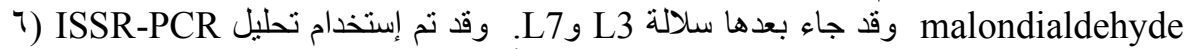

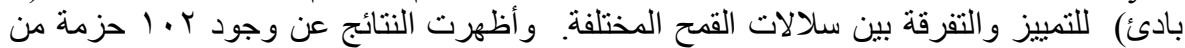

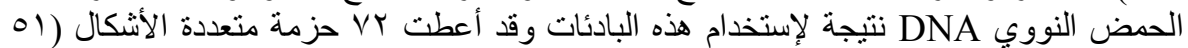

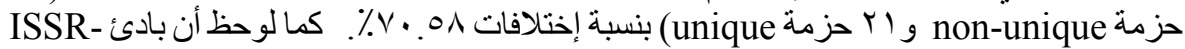

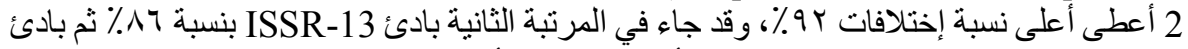
ISSR-11

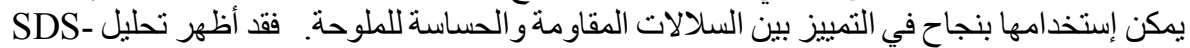

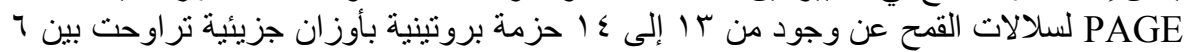

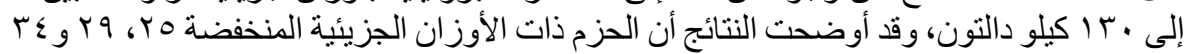

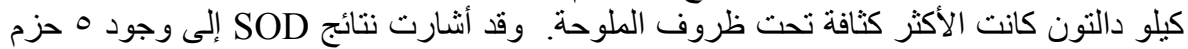

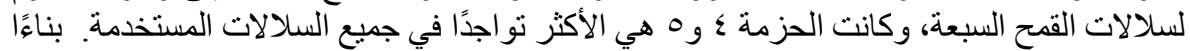

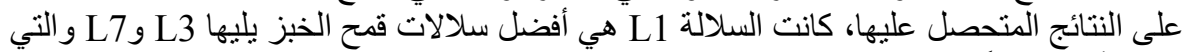

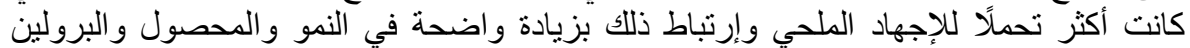

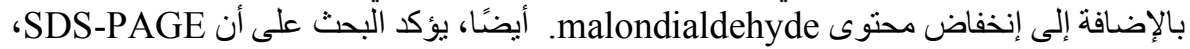
ISSR و طرق مفيدة وهامة للتمييز بين سلالات قمح الخبز المختلفة تحت الظروف الملحية. 